\title{
17. Paleoclimatic Features in Central Japan based on the Stable Isotope Compositions of Lake Biwa Sediments and Speleothems
}

\author{
By Nobuyuki NAKAI and Yasutoshi SHIRAI \\ Department of Earth Sciences, Faculty of Science, Nagoya University \\ (Communicated by Kenjiro KimurA, M. J. A., March 13, 1978)
}

Introduction. To study climatic changes of Japanese Island in the past, $200 \mathrm{~m}$-cored sediments have been obtained from the bottom of Lake Biwa. According to Kanari's estimation (1975) based on several pieces of data of ${ }^{14} \mathrm{C}$ and fission-track ages, the deepest horizon of the cored column showed the age of $550 \times 10^{3}$ years B.P. One of the present writers previously reported the vertical variations of organic carbon contents and the ${ }^{13} \mathrm{C} /{ }^{12} \mathrm{C}$ ratios of the sediments and suggested that the ${ }^{13} \mathrm{C} /{ }^{12} \mathrm{C}$ ratios widely fluctuated through the cored column and the fluctuation is caused by cyclic paleoclimate changes (Nakai 1972, 1975).

In the present paper, the climatic fluctuation deduced from our carbon isotope study of Lake Biwa sediments will be discussed in connection with the vertical profile of fossil diatom numbers (Mori 1974), climates estimated by palynological studies (Fuji and Horie 1977) and paleogeomagnetic polarity changes (Kawai et al. 1972) for the same core samples. In addition to the climatic studies that have used the Lake sediments, the climatic changes measured in detail by ${ }^{18} \mathrm{O} /{ }^{16} \mathrm{O}$ ratios of speleothem $\mathrm{CaCO}_{3}$ will be reported for the past $37 \times 10^{3}$ years.

Experimental procedure. Sediment samples for ${ }^{13} \mathrm{C} /{ }^{12} \mathrm{C}$ analyses were taken at intervals of $5 \mathrm{~m}$ from the cored column of $200 \mathrm{~m}$ length and analyzed with respect to ${ }^{13} \mathrm{C} /{ }^{12} \mathrm{C}$ ratios as described by Nakai (1972). Stalactite and flowstone samples were collected from Otaki Cave, Gifu Prefecture, near Lake Biwa. The $\mathrm{CaCO}_{3}$ samples were drilled out of the cross-section of stalactite and the vertical section of flowstone at every interval of 1 to $5 \mathrm{~mm}$ and analyzed for ${ }^{18} \mathrm{O} /{ }^{16} \mathrm{O}$ ratios as reported by Epstein et al. (1953) and for ages by the ${ }^{14} \mathrm{C}$ method. The isotopic data for both of carbon and oxygen are presented as per mil deviation from the $\mathrm{PDB}\left({ }^{13} \mathrm{C} /{ }^{12} \mathrm{C}=0.0112372\right)$ and $\mathrm{SMOW}$ $\left({ }^{18} \mathrm{O} /{ }^{16} \mathrm{O}=0.0019934\right)$ standards, respectively. This deviation is defined by

$$
\delta^{13} \mathrm{C} \text { or } \delta^{18} \mathrm{O}(\% o)=\frac{\mathrm{R}(\text { sample })-\mathrm{R}(\text { standard })}{\mathrm{R}(\text { standard })} \times 1000 .
$$


Results and discussions. Lake Biwa sediments. The organic C in sediment has been reported to have a range of $\delta^{13} \mathrm{C}$ values from -31.8 to $-37.9 \%$ and the contents from 0.3 to $1.2 \%$ in dry samples. Large vertical fluctuation in $\delta^{13} \mathrm{C}$ values (Fig. 1) has been explained by changes of the kinetic isotope effect with temperature during the past photosynthetic process in the lake (Nakai 1972, 1975). A general feature of these results obtained so far seems to be a tendency toward larger $\delta^{13} \mathrm{C}$ values when organic carbon contents, amounts of organic residues, are larger. So, one can expect the tendency toward larger $\delta^{13} \mathrm{C}$ values of photosynthetic products when the climate is temperate or warmer. For the same core samples, Mori (1974) studied the species composition of fossil diatoms and reported the vertical profile of total fossil diatom cell numbers as shown in Fig. 1. This fluctuation trend through the entire core column gives excellent agreement with that of $\delta^{13} \mathrm{C}$ values. The periods of abundant diatom cells correlate well with the periods of the larger $\delta^{13} \mathrm{C}$ values. In Fig. $2, \delta^{13} \mathrm{C}$ values of organic $\mathrm{C}$ are plotted against the numbers of total diatom cells. It appears that this figure shows no correlation between them. However, if sediment layers with the limited thickness are separately considered, an excellent linear relation between them can be found within each of layers. This means that $\delta^{13} \mathrm{C}$ values of sedimentary organic $\mathrm{C}$ and the past productivity of the lake have a different linear

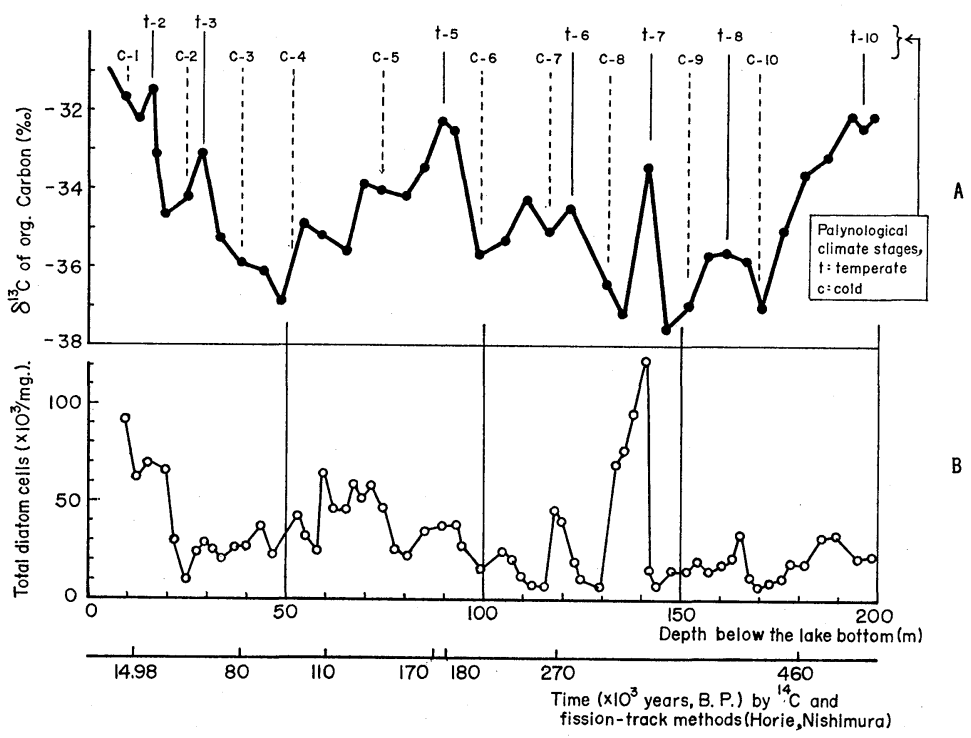

Fig. 1. Vertical profile for $\delta^{13} \mathrm{C}$ values of organic carbon (A) and for fossil diatom numbers by Mori (1974) (B) in Lake Biwa sediments. (Absolute ages by Horie et al. (1971) and Nishimura et al. (1974, 1975), and palynological climate stages by Fuji and Horie (1977) were used.) 


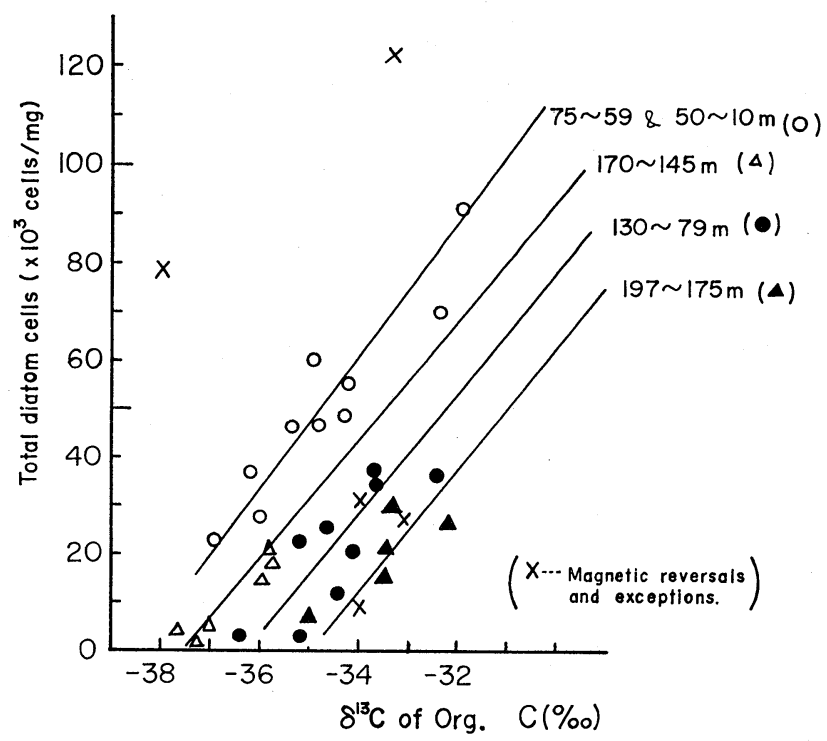

Fig. 2. Relationship between $\delta^{13} \mathrm{C}$ values of organic materials and total diatom cell numbers in the sediment column from Lake Biwa.

relation in each different period. These linear relationships make up different lines before and after the geomagnetic reversal period reported by Kawai et al. (1972). It may be considered that the short reversed polarity events have some effects upon the $\delta^{13} \mathrm{C}$ values of photosynthetic products. Apart from the reason, $\delta^{13} \mathrm{C}$ values of fossil organic materials can be used as an indicator of the past productivity and temperature fluctuation within the limited period.

Fuji and Horie (1977) established the paleotemperature curve of the $200-\mathrm{m}$ core samples on the basis of the palynological studies. They found 10 temperate and 12 cold periods during the last $550 \times 10^{3}$ years, and have named them $t-1, t-2, \ldots$, and $c-1, c-2, \ldots$, respectively, from young to old period. In Fig. 1, the climatic periods deduced from this study are indicated on the $\delta^{13} \mathrm{C}$ fluctuation curve. As shown in this figure, an excellent correlation can be seen between the $\delta^{13} \mathrm{C}$ paleoclimatic fluctuations and the palynological paleoclimate. In a palynologically temperate climate $\delta^{13} \mathrm{C}$ of organic C gives relatively large values and in a cold climate relatively small values with exceptions of $t-4, c-11$ and $c-12$.

From a comparison of the $\delta^{13} \mathrm{C}$ results with the fossil diatom and pollen studies, it is clearly concluded that the $\delta^{13} \mathrm{C}$ fluctuation of fossil organic materials undoubtedly reflects changes in the past temperatures.

Considering the $\delta^{13} \mathrm{C}$ fluctuation and the absolute ages in Fig. 1, the glacial ages based on the $\delta^{13} \mathrm{C}$ values can be examined for corre- 
spondence with the established European and North American glacial ages. The last glacial age, Würm or Wisconsin, corresponds to the $\delta^{13} \mathrm{C}$ drops at 10 to $30 \mathrm{~m}$ in depth of the Lake Biwa sediment column. The earlier cold period with $\delta^{13} \mathrm{C}$ values lowering between the depths of 60 and $70 \mathrm{~m}$ may be considered to be the Riss glacial age, and that between the depths of 95 and $105 \mathrm{~m}$ to be the Mindel glacial age. The cold period of the minimum $\delta^{13} \mathrm{C}$ value at the depth of about $135 \mathrm{~m}$ may possibly correspond to the Güntz glacial age. The drops of $\delta^{13} \mathrm{C}$ values at the depth of 45 to $50 \mathrm{~m}, 145 \mathrm{~m}$, and $170 \mathrm{~m}$ cannot correspond to any known glacial age. However, the climatic estimation based on the measurement of $\delta^{18} \mathrm{O}$ of ice sheets from Greenland and Arctic Canada indicates a cold stage around $90 \times 10^{3}$ years B.P. during the Sangamon interglacial age between the Würm and the Riss glacial age (Johnsen et al. 1972; Paterson et al. 1977). This cold stage chronologically agrees well with the isotope cold stage at the depth of 45 to $50 \mathrm{~m}$ in the Lake Biwa sediment column.

Speleothems from Gifu Prefecture. Other than the climatic studies by using the Lake Biwa sediments, an attempt has been made to measure ${ }^{18} \mathrm{O} /{ }^{16} \mathrm{O}$ of the cave $\mathrm{CaCO}_{3}$ for the last glacial age to Holocene.

Hendy and Wilson (1968) found the temperature-dependent fluctuations in the $\delta^{18} \mathrm{O}$ of calcite deposited on speleothems in New Zealand. The present authors tried to calculate directly the deposition temperature by a method different from Hendy's in the following manner. In an isotopic exchange equilibrium of oxygen isotopes between calcite and water in which calcite was deposited, the isotopic fractionation is a function of the temperature. The isotopic equilibrium fractionation factor, $\alpha$, can be expressed as a function of temperature $\left({ }^{\circ} \mathrm{K}\right)$ according to the following equation (O'Neil et al. 1969) :

$$
\delta^{18} \mathrm{O}\left(\mathrm{CaCO}_{3}\right)-\delta^{18} \mathrm{O}\left(\mathrm{H}_{2} \mathrm{O}\right) \fallingdotseq 1000 \ln \alpha_{\mathrm{H}_{2} \mathrm{O}}^{\mathrm{CaCO}_{3}}=2.78\left(10^{6} \mathrm{~T}^{-2}\right)-3.39 .
$$

The $\delta^{18} \mathrm{O}$ values of the water passing through the speleothem surface in the past are in turn determined by those of the rain waters in the region. Dansgaard (1964) has reported that the annual average value of the $\delta^{18} \mathrm{O}$ of rain for the coastal regions at middle to high latitudes varies lineraly with the mean annual air temperature, $t\left({ }^{\circ} \mathrm{C}\right)$, according to the following equation:

$$
\delta^{18} \mathrm{O}\left(\mathrm{H}_{2} \mathrm{O}\right)_{\text {SMOW }}=0.695 \mathrm{t}-\mathrm{A} \text {, }
$$

where A is a constant, to which Dansgaard (1964) has gievn the value of 13.6 for the North Atlantic coast and Greenland. But our estimation for Central Japan indicates A to be 15.2.

Substituting the measured values of $\delta^{18} \mathrm{O}$ into the equation (1) and eliminating the $\delta^{18} \mathrm{O}\left(\mathrm{H}_{2} \mathrm{O}\right)$ from the equations (1) and (2), the temperature can be calculated. The calculated temperatures range 
Table I. Oxygen isotopic compositions of speleothems from

Otaki Cave and the temperatures by the isotopic compositions

\begin{tabular}{lcc}
\hline Speleothems & $\delta^{18} \mathrm{O}(\mathrm{SNOW}, \%)$ & Isotopic temp. $\left({ }^{\circ} \mathrm{C}\right)$ \\
\hline Flowstone I & $+23.7-+25.2$ & $11.7-15.0$ \\
Stalactite & $+23.2-+24.3$ & $10.6-13.0$ \\
Flowstone II & $+23.2-+24.0$ & $10.6-12.3$ \\
\hline
\end{tabular}

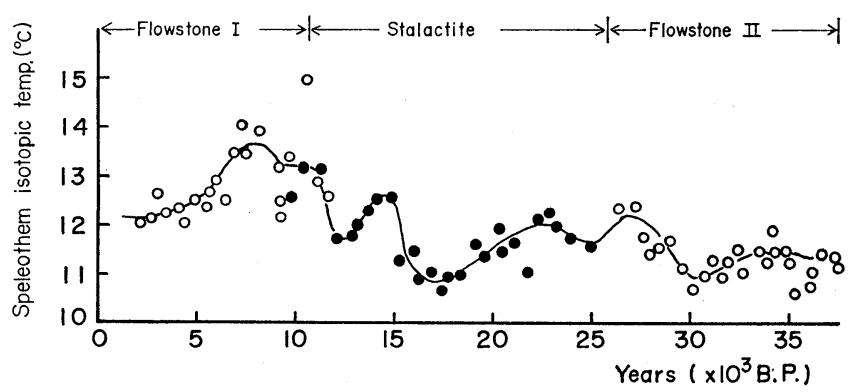

Fig. 3. Temperature variations during the last 37,000 years estimated by $\delta^{18} \mathrm{O}$ measurements of speleothems from Otaki cave, Central Japan.

from 10.6 to $15.0^{\circ} \mathrm{C}$ as presented in Table I. By connecting results obtained from two flowstones and a stalactite which overlap each other chronologically, a paleotemperature curve can be drawn for the last $37 \times 10^{3}$ years, as shown in Fig. 3. In this figure, only a point around $10 \times 10^{3}$ years B.P. is separated considerably from other points of similar ages. So, this point is eliminated in drawing a smoothed climatic curve. The feature of the paleoclimatic fluctuation curve indicates that the Late Würm glacial age and the Holocene warm period can apparently be seen before and after about $10 \times 10^{3}$ years B.P., respectively. During the Late Würm glacial age, extremely cold stages, Stadials, can be found in the ages of 17 to $18 \times 10^{3}$ years B.P. and $30 \times 10^{3}$ years B.P., and a relatively warm stage, Interstadial, in an age of 20 to $27 \times 10^{3}$ years B.P. These Stadial and Interstadial stages chronologically agree well with the climatic estimations from the sea level changes (Minato 1966; Fairbridge 1961) and from $\delta^{18} \mathrm{O}$ of ice sheets (Paterson et al. 1977; Johnsen et al. 1972). During Holocene we can find a temperature maximum in the age of 7 to $8 \times 10^{3}$ years B.P., and the temperature decreases continuously toward the present time. The above-estimated temperatures show that of water in the cave in the strict sense. The time resolution of this method is much better than that estimated by $\delta^{18} \mathrm{O}$ of foraminifera from the deep sea cores, having an average of one point $/ 450$ years.

As reported above, the carbon and oxygen isotope methods have 
been applied to Lake Biwa sediments and speleothems, respectively, to estimate the paleotemperature variations of Central Japan. Our comparison of the climatic profiles obtained by isotopic and several other methods did not only give close agreement among themselves but unknown short cold periods also could be found by these isotopic methods applied to Lake Biwa sediments and speleothems.

\section{References}

Dansgaard, W. (1964) : Tellus, 16, 436.

Epstein, S., Buchsbaum, R., Lowenstam, H., and H. C. Urey (1953) : Bull. Geol. Soc. Am., 64, 1315.

Fairbridge, R. W. (1961) : Physics and Chemistry of the Earth, 4 (L. H. Ahens et al. ed.), 99.

Fuji, N., and S. Horie (1977) : Proc. Japan Acad., 53, 139.

Hendy, C. H., and A. T. Wilson (1968) : Nature, 219, 48.

Johnsen, S. J., Dansgaard, W., Clausen, H. B., and C. C. Langway, Jr. (1972) : Nature, 235, 429.

Kanari, S., and Y. Takenoya (1975): Paleolimnology of Lake Biwa and the Japanese Pleistocene (S. Horie ed.), vol. 3, pp. 235-240.

Kawai, N., Yaskawa, K., Nakajima, T., Torii, M., and S. Horie (1972) : Proc. Japan Acad., 48, 186.

Minato, M. (1966) : Earth Science (Chikyu Kagaku), nos. 85/86, 2.

Mori, S. (1974) : Paleolimnology of Lake Biwa and the Japanese Pleistocene (S. Horie ed.), vol. 2, pp. 247-252.

Nakai, N. (1972) : Proc. Japan Acad., 48, 516. (1975): Paleolimnology of Lake Biwa and the Japanese Pleistocene (S. Horie ed.), vol. 3, pp. 250-256.

O'Neil, J. R., Clayton, R. N., and T. K. Mayeda (1969) : J. Chem. Phys., 51, 5547.

Paterson, W. S. B., Koerner, R. M., Fisher, S., Johnsen, S. J., Clausen, H. B., Dansgaard, W., Bucher, P., and H. Oeschger (1977) : Nature, 266508. 